\title{
Heterosis and Combining Ability for Grain Yield and Yield Component Traits of Maize in Eastern Ethiopia
}

\author{
Habtamu Zeleke* \\ School of Plant Sciences, P.O. Box: 76, Haramaya University, Dire Dawa, Ethiopia
}

\begin{tabular}{|c|c|}
\hline Abstract & Article Information \\
\hline \multirow{5}{*}{ 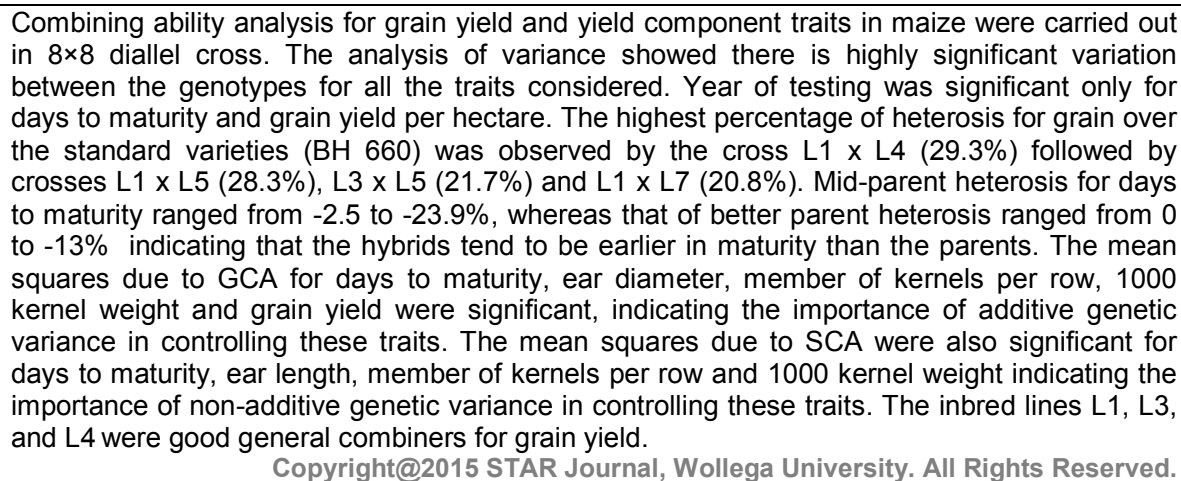 } & $\begin{array}{ll}\text { Article History: } \\
\text { Received }: 03-06-2015 \\
\text { Revised }: 04-09-2015 \\
\text { Accepted }: 23-09-2015\end{array}$ \\
\hline & $\begin{array}{l}\text { Keywords: } \\
\text { Maize } \\
\text { Combining ability } \\
\text { General combining ability } \\
\text { Specific combining ability } \\
\text { Standard heterosis }\end{array}$ \\
\hline & $\begin{array}{l}{ }^{*} \text { Corresponding Author: } \\
\text { Habtamu Zeleke }\end{array}$ \\
\hline & \\
\hline & \\
\hline
\end{tabular}

\section{INTRODUCTION}

In Ethiopia, maize (Zea mays L.) is one of the most important crops and is grown across 13 agro-ecological zones in Ethioipia. It is the first crop in production more than any other cereal crop in the country. Over half of all Ethiopian farmers grow maize, mostly for subsistence, with $75 \%$ of all maize produced in the country is consumed as human food.

According to a 2012 FAO report, Ethiopia is the fourth largest maize producing country in Africa, and first in the East African region. It is also significant that Ethiopia produces non-genetically modified (GMO) white maize, the preferred type of maize in neighboring markets (CSA, 2013). Based on area of production major cereals in the country, teff ranked first, followed by maize, sorghum and wheat, respectively, whereas maize ranks first in total grain production, followed by teff, wheat and sorghum (CSA, 2014).

Hybrid cultivars have been contributing immensely in increasing area allotted for maize production and productivity of maize per unit area of production (Kanagarasu, 2010). In Ethiopia, the averages yield in kilogram per hectare at national level was increased by $4.8 \%$ in 2012-2013 (CSA, 2013). Out of the total grain crop area, $79.38 \%(9,848,745.96$ hectares) was under cereals of which $16.08 \%$ was occupied by maize $(1,994,813.80$ hectares $)$. Cereals contributed $85.81 \%$ $(583,522.561$ tons) of the grain production from which maize made up $25.81 \%$ (21583522.56 tones). Maize yield was also increased from $5.41 \%$ (3.059 tons per hectare) to $6.37 \%$ (3.254 tons per hectare in 2012-2013 (CSA,
2014). Ethiopia's current national maize yield is 3.25 metric tons per hectare, $28 \%$ above the developing world average of $2.5 \mathrm{MT} / \mathrm{ha}$. The 'developed' world, however, see average yields of $6.2 \mathrm{MT} / \mathrm{ha}$, with some countries actually exceeding $10 \mathrm{MT} / \mathrm{ha}$ (CSA, 2013). The above results show progress of maize production in Ethiopia for own consumption and/or economic benefits. The benefits are results of the use improved maize varieties, particularly conventional type of hybrids.

Currently, concentrated efforts are underway in the country by different maize research institutions to move more toward the use of hybrids varieties. To fulfill this aim, combining ability studies have prime importance in maize hybrid development since it provides information for the selection of parents and also provides information on the nature and magnitude gene actions. The two types of combining ability, general (GCA) and specific (SCA) have been recognized in genetic studies. General combining ability relates to additive gene effects, while specific combining ability reflects the non-additive gene actions (Sprague and Tatum, 1942). GCA is average performance of a parent in a series of crosses and SCA designates those cases in which certain combinations perform relatively better or worse than would be expected on the basis of average performance of parents. The GCA includes additive and additive $\times$ additive variances, while SCA is responsible for non-additive genetic variances (Ibni Amin Khalil, 2010). In specific combining ability; dominance or epistatic effects of genes are commonly involved in maize (Rahman, 2013). With this aim in mind, this research was conducted with the objective to study 
Habtamu Zeleke

heterosis and combining ability in maize (Zea mays L.) for yield and yield related traits in eastern Ethiopia.

\section{MATERIALS AND METHODS}

\section{Planting Materials}

The experimental materials comprised of $28 \mathrm{~F}_{1}$ hybrids obtained from a cross between 8 inbred lines in a diallel fashion plus the parental lines and one standard check (BH 660). The description of the lines is depicted in table 1. All the lines have been developed by Haramaya University Maize Research Program. $F_{1}$ hybrids have been obtained by crossing in $8 \times 8$ diallel mating design in the main cropping season of 2010.

Table 1. List of lines used in the study

\begin{tabular}{cccc}
\hline No. & Inbred line & Kernel color & Maturity type \\
\hline 1. & AL-165 & White & Late \\
2. & Al-173 & White & Late \\
3. & AL-183 & White & Late \\
4. & AL-186 & White & Late \\
5. & AL99-AL-119 & White & Late \\
6. & AL99-AL-151 & White & Late \\
7. & AL99-AL-270 & White & Late \\
8. & AL99-AL-79 & White & Late \\
\hline
\end{tabular}

Source: Haramaya University Maize Research Program

\section{Methods}

The $28 F_{1}$ hybrids plus the parental lines were tested in 2011/2012 and 2012/13 cropping seasons for two years at Haramaya University main campus (Raare research site) using randomized complete block design with three replication. Each plot consisted of four rows with row length of $5.1 \mathrm{~m}$. Tow Seeds were sown per hill and at 4-5 leaf stage thinned to one plant per hill. The distance between rows and between plants with in the row was maintained at $0.75 \mathrm{~m}$ and $0.30 \mathrm{~m}$, respectively. At sowing, $\mathrm{P}_{2} \mathrm{O}_{5}$ at the rate of $46 \mathrm{~kg} / \mathrm{ha}$ in a form of DAP and $35 \mathrm{~kg} / \mathrm{ha}$ of $\mathrm{N}$ in a form of urea was applied. At about booting stage, $35 \mathrm{~kg} / \mathrm{ha} \mathrm{N}$ was also applied. All other field management practices including stalk borer and armyworm control were done as required. Data were collected from the middle two rows leaving the end hills. Data were collected on days to maturity, ear length, ear diameter, number of rows per ear, number of kernel rows per ear, 1000 kernel weight $(\mathrm{g})$ and grain yield in $\mathrm{t} / \mathrm{ha}$. Before analysis of the data, both grain yield and 1000 kernel weight were adjusted to $12.5 \%$ moisture content.
Sci. Technol. Arts Res. J., July-Sep 2015, 4(3): 32-37

\section{Statistical Analysis}

All data were subjected to simple analysis of variance to see the existence of genetic whether there are differences between the tested genotypes before running combining ability analysis. Analysis of variance for general combining ability (GCA) and specific combining ability (SCA) was done following Method II, Model I as suggested by Griffing (1956).

Heterosis expressed as increase or decrease of $F_{1}$ hybrid value over mid-parent (relative heterosis), better parent (heterobeltiosis) and over the best commercial check (standard heterosis) were calculated for each character using the following formulas suggested by Hayes et al. (1955).

$\left(\frac{\text { F1-MP }}{\text { MP }}\right) \times 100=$ Heterosis over mid parent (relative heterosis) $\left(\frac{\mathrm{F} 1-\mathrm{BP}}{\mathrm{BP}}\right) \times 100=$ Heterosis over better parent (heterobeltiosis) $\left(\frac{\text { F1 - STV }}{\text { STV }}\right) \times 100=$ Heterosis over check (standard heterosis)

Where: $F_{1}=$ mean performance of $F_{1}, M P=$ mean midparental value $=(\mathrm{P} 1+\mathrm{P} 2) / 2, \mathrm{P} 1=$ mean performance of parent one, $\mathrm{P} 2=$ mean performance of parent two, $\mathrm{BP}=$ mean performance of better parent, $C C=$ mean performance of the best commercial check.

\section{RESULTS AND DISCUSION}

\section{Analysis of Variance}

The analysis of variance showed highly significant differences between the genotypes for grain yield, days to maturity and yield component traits indicating there is sufficient genetic variation among the tested genotypes. Several maize researchers also found statistically significant differences between the genotypes for grain yield and yield related traits in their study on heterosis and combining ability of maize (Dagne et al., 2007; Amiruzzaman et al., 2010; Amanullah et al., 2011 and Shushay et al., 2014). Days to maturity and grain yield showed statistically highly significant difference between the genotypes in their response to seasonal variation/year of testing. Significant genotype $x$ year of testing interaction was detected for 1000 kernel weight and grain yield indicating the need for testing varieties/genotypes over locations and seasons in order to see their performance under the different environments (Table 2). Similar result was also noticed by Dagne et al., 2007).

Table 2: Mean squares due to grain yield and yield components of maize (Zea mays L.) in eastern Ethiopia

\begin{tabular}{lclcccccc}
\hline Source of Variation & d.f. & DM & EL $(\mathbf{c m})$ & ED $(\mathbf{c m})$ & KRE & KR & TKWT (g) & GY (t/ha) \\
\hline Replication & 2 & 320.73 & 6.25 & 0.205 & 3.17 & 248.14 & 938.91 & 0.87 \\
Genotype (G) & 35 & $3536.46^{* *}$ & $6.68^{* *}$ & $0.23^{* *}$ & $3.10^{* *}$ & $59.89^{* *}$ & $29012.82^{* *}$ & $15.39^{* *}$ \\
Year (Y) & 1 & $19.40^{* *}$ & 0.18 & 0.02 & 0.02 & 10.23 & 573.63 & $87.70^{* *}$ \\
G x Y & 35 & 9.36 & 2.36 & 0.07 & 1.58 & 18.10 & $1779.20^{*}$ & $3.25^{* *}$ \\
Error & 142 & 11.26 & 1.86 & 0.14 & 2.06 & 23.56 & 1109.12 & 1.23 \\
\hline , $^{* *}=$ significant at 0.05 and 0.01 level of significant, respectively and d.f. = degrees of freedom, DM = Days to maturity; EL = Ea
\end{tabular}

length; $\mathrm{ED}=$ Ear diameter; $\mathrm{KRE}=$ Kernel rows per ear; $\mathrm{KR}=$ Kernels per row; TKWT = Thousand kernel weight; $\mathrm{GY}=\mathrm{Grain}$ yield

\section{Mean Performance of Genotypes $F_{1}$ Hybrids and Parents}

There were significant differences between the genotypes for grain yield (table 3). The yield of the crosses ranged from $7.15-10.15 \mathrm{~kg} / \mathrm{ha}$. Top yielding crosses were L1 x L4 (10.15 t/ha), L1 x L5 (10.05 t/ha), L7 x L8 (10.04 t/ha), L3 x L8 (9.60 t/h), L3 x L5 (9.55 t/ha), L1 x L7 (9.48 t/ha), L3 x L6 (9.16 t/ha, L3 x L7 (9.01 t/ha) produced over $9 \mathrm{t} /$ ha of grain per hectare, whereas the yield of lines ranged from 4.53-6.12 t/ha (Table 3). 
Table 3: Mean performance of maize crosses and lines for grain yield and yield components of maize (Zea mays L.) in Eastern Ethiopia

\begin{tabular}{|c|c|c|c|c|c|c|c|}
\hline No. & Crosses & $\begin{array}{c}\text { Ear } \\
\text { Length (cm) }\end{array}$ & $\begin{array}{c}\text { Ear } \\
\text { Diameter }(\mathbf{c m})\end{array}$ & $\begin{array}{c}\text { Kernel } \\
\text { Rows per ear }\end{array}$ & $\begin{array}{l}\text { Kernels } \\
\text { per row }\end{array}$ & $\begin{array}{c}\text { Thousand } \\
\text { Kernel weight (g) }\end{array}$ & $\begin{array}{c}\text { Grain yield } \\
\text { (t/ha) }\end{array}$ \\
\hline 1 & $\mathrm{~L} 1 \times \mathrm{L} 2$ & 16.55 & 4.14 & 14.00 & 33.00 & 373.00 & 8.33 \\
\hline 2 & L $1 \times$ L 3 & 17.33 & 3.98 & 12.00 & 36.00 & 366.67 & 3.83 \\
\hline 3 & $\mathrm{~L} 1 \times \mathrm{L} 4$ & 16.67 & 4.17 & 12.00 & 32.00 & 390.00 & 10.15 \\
\hline 4 & $\mathrm{~L} 1 \times \mathrm{L} 5$ & 17.20 & 4.26 & 12.00 & 34.00 & 396.00 & 10.07 \\
\hline 5 & $\mathrm{~L} 1 \times \mathrm{L} 6$ & 16.67 & 3.85 & 12.00 & 34.00 & 371.33 & 7.88 \\
\hline 6 & L $1 \times$ L 7 & 16.71 & 4.23 & 12.00 & 38.00 & 361.00 & 9.48 \\
\hline 7 & L $1 \times$ L 8 & 16.19 & 3.99 & 12.00 & 31.00 & 383.00 & 8.67 \\
\hline 8 & $\mathrm{~L} 2 \times \mathrm{L} 3$ & 16.67 & 4.55 & 12.00 & 37.00 & 394.00 & 8.91 \\
\hline 9 & $\mathrm{~L} 2 \times \mathrm{L} 4$ & 17.31 & 4.45 & 12.00 & 32.00 & 3.61 .17 & 8.28 \\
\hline 10 & L $2 \times L 5$ & 17.21 & 4.62 & 12.00 & 38.00 & 395.67 & 8.94 \\
\hline 11 & $\mathrm{~L} 2 \times \mathrm{L} 6$ & 17.41 & 3.38 & 12.00 & 37.00 & 386.00 & 8.40 \\
\hline 12 & $\mathrm{~L} 2 \times \mathrm{L} 7$ & 17.28 & 3.86 & 12.00 & 38.00 & 407.67 & 8.31 \\
\hline 13 & $\operatorname{L~} 2 \times \operatorname{L} 8$ & 16.61 & 4.38 & 14.00 & 37.00 & 369.17 & 7.88 \\
\hline 14 & $\mathrm{~L} 3 \times \mathrm{L} 4$ & 16.92 & 3.98 & 12.00 & 30.00 & 390.00 & 8.73 \\
\hline 15 & $\operatorname{L} 3 \times \operatorname{L~} 5$ & 18.04 & 4.24 & 12.00 & 40.00 & 407.67 & 9.55 \\
\hline 16 & $\mathrm{~L} 3 \times \mathrm{L} 6$ & 16.92 & 4.34 & 12.00 & 38.00 & 335.83 & 9.16 \\
\hline 17 & $\mathrm{~L} 3 \times \operatorname{L} 7$ & 16.54 & 4.42 & 12.00 & 40.00 & 389.83 & 9.01 \\
\hline 18 & L $3 \times \operatorname{L~} 8$ & 17.42 & 4.08 & 12.00 & 41.00 & 408.33 & 9.60 \\
\hline 19 & $\mathrm{~L} 4 \times \mathrm{L} 5$ & 16.62 & 4.34 & 12.00 & 39.00 & 375.67 & 8.35 \\
\hline 20 & $\operatorname{L} 4 \times \operatorname{L} 6$ & 17.54 & 4.13 & 12.00 & 34.00 & 397.50 & 8.31 \\
\hline 21 & L $4 \times$ L 7 & 17.17 & 3.90 & 10.00 & 37.00 & 378.50 & 7.15 \\
\hline 22 & L $4 x$ L 8 & 17.38 & 4.49 & 12.00 & 31.00 & 391.33 & 7.33 \\
\hline 23 & L $5 \times \operatorname{L~} 6$ & 17.54 & 4.28 & 12.00 & 37.00 & 367.50 & 8.52 \\
\hline 24 & L $5 \times$ L 7 & 16.58 & 4.28 & 10.00 & 34.00 & 387.83 & 8.10 \\
\hline 25 & L $5 \times \operatorname{L~} 8$ & 17.21 & 4.21 & 14.00 & 36.00 & 371.33 & 8.85 \\
\hline 26 & $\mathrm{~L} 6 \times \mathrm{L} 7$ & 18.08 & 4.26 & 12.00 & 37.00 & 387.67 & 8.89 \\
\hline 27 & L $6 \times$ L 8 & 17.50 & 4.21 & 10.00 & 38.00 & 390.83 & 7.71 \\
\hline 28 & L $7 \times$ L 8 & 17.08 & 4.23 & 12.00 & 33.00 & 338.33 & 10.04 \\
\hline 29 & L 1 (Line 1) & 14.52 & 3.87 & 12.00 & 31.00 & 139.00 & 4.84 \\
\hline 30 & L 2 (Line 2) & 14.21 & 4.29 & 14.00 & 36.00 & 254.67 & 5.22 \\
\hline 31 & L 3 (Line 3) & 14.95 & 4.28 & 12.00 & 34.00 & 245.83 & 6.12 \\
\hline 32 & L 4 (Line 4) & 14.83 & 4.24 & 12.00 & 39.00 & 208.67 & 4.53 \\
\hline 33 & L 5 (Line 5) & 15.33 & 4.32 & 12.00 & 36.00 & 287.50 & 5.45 \\
\hline 34 & L 6 (Line 6) & 14.08 & 4.40 & 12.00 & 35.00 & 225.17 & 5.36 \\
\hline 35 & L 7 (Line 7) & 16.04 & 4.09 & 12.00 & 38.00 & 180.50 & 5.48 \\
\hline 36 & L 8 (Line 8) & 14.51 & 4.44 & 10.00 & 27.00 & 332.50 & 5.33 \\
\hline \multirow{2}{*}{\multicolumn{2}{|c|}{$\begin{array}{c}\text { LSD }_{\mathrm{P} 0.01} \\
\mathrm{CV} \%\end{array}$}} & 2.056 & 0.387 & 1.638 & 7.317 & 50.20 & 1.670 \\
\hline & & 8.220 & 8.960 & 12,210 & 13.680 & 9.55 & 13.960 \\
\hline
\end{tabular}

Statistically significant differences (LSD at $\mathrm{P}_{0.01}$ level of significance) have been observed for all yield related traits (Table 3). Days to maturity ranged from 157-173. Almost all the hybrids were relatively earlier that the parents. L8 was the latest to reach maturity, where as the hybrid $L 2 x$ L3 was the fastest to mature. Ear length ranged from $14.08-18.08 \mathrm{~cm}$. Inbred lines exhibited shorter ear length compared to the hybrids. Ear diameter ranged from 3.38$4.49 \mathrm{~cm}$; average kernel rows per ear ranged from $10-$ 12; kernels per row from 27-41 and 1000 kernel weight from 138-408 grams obtained by L1 and L3 x L5, respectively. The top yielding hybrids also showed medium to high values for yield components.

\section{Heterosis for Yield and Yield Related Traits}

Percent (\%)mid-parent (MPH), better parent $(\mathrm{BPH})$ and standard heterosis (STH) were computed for grain yield and related traits (table 4 ). STH was considered only for grail yield. The top ten high yielding crosses significant and high MPH, BPA and standard heterosis compared to the remaining crosses. MPH for grain yield ranged from
42.9 to $116.6 \%$, for $\mathrm{BPH}$ from 33.4 to $113.3 \%$ and for standard STH from -8.9 to $29.9 \%$ (Table 4). Amiruzzaman et al. (2010) in their study on combining ability and heterosis for yield and yield components reported similar result. Rodrigo et al. (2012) also reported statistical significant heterosis for yield and different agronomic traits in their study on genetic divergence among maize hybrids and correlations with heterosis and combining ability.

Both mid-parent and better parent heterosis for days to maturity are negative for all the crosses. For this trait, midparent heterosis ranged from -2 to $-13 \%$ and better parent heterosis -5 to $-23 \%$. This showed that hybrids tend to be earlier in maturity compared to their parents. In this study, ear diameter, number of rows per ear and number of kernels per row showed low/negligible level of heterosis, whereas ear length and 1000 kernel weight produced relatively high and positive heterosis. The range of midparent and better parent heterosis for ear length was 5.7 to $20.1 \%$ and -13 to $18.3 \%$, respectively, whereas midparent and better parent heterosis for 1000 kernel weight 
Habtamu Zeleke

was -5.8 to $126.6 \%$ and 1.8 to $100.6 \%$, respectively (table 4). Praveen Kumar et al. (2014) in their study on heterosis for grain yield and its component traits in maize (Zea mays L.) also reported positive and significant heterosis
Sci. Technol. Arts Res. J., July-Sep 2015, 4(3): 32-37

for yield component traits. Similarly findings were reported by Dagne et al. (2009), Amnnullah et al. (2011) and Ali et al. (2014) in their study on maize.

Table 4: Heterosis (\%) for yield related traits and grain yield of maize (Zea mays L.) in eastern Ethiopia

\begin{tabular}{|c|c|c|c|c|c|c|c|c|c|c|c|c|c|c|c|}
\hline \multirow{2}{*}{ Cross } & \multicolumn{2}{|c|}{$\begin{array}{l}\text { Days to } \\
\text { Maturity }\end{array}$} & \multicolumn{2}{|c|}{$\begin{array}{c}\text { Ear } \\
\text { Length }\end{array}$} & \multicolumn{2}{|c|}{ Ear diameter } & \multicolumn{2}{|c|}{ Rows/ear } & \multicolumn{2}{|c|}{$\begin{array}{c}\text { Kernels/ } \\
\text { Row }\end{array}$} & \multicolumn{2}{|c|}{1000 kwt } & \multicolumn{3}{|c|}{ Grain yield } \\
\hline & MPH & $\mathrm{BPH}$ & MPH & $\mathrm{BPH}$ & MPH & BPH & MPH & BPH & MPH & $\mathrm{BPH}$ & MPH & BPH & MPH & $\mathrm{BPH}$ & STH \\
\hline L1 x L2 & -19.0 & -10 & 12.4 & 8.8 & 1.5 & -3.7 & 6.9 & -2.3 & -2.7 & 5.4 & 84.8 & 40.9 & 67.1 & 64.2 & 6.1 \\
\hline L1 x L3 & -13.8 & -6 & 14.8 & 13.8 & -2.3 & -7.4 & 3.0 & -12.3 & 12.4 & 7.4 & 90.6 & 49.2 & 61.1 & 49.5 & 12.5 \\
\hline L1 $x$ L4 & -11.1 & -3 & 10.8 & 9.4 & 2.8 & -1.7 & 6.1 & -12.3 & -7.6 & -17.9 & 51.6 & 86.9 & 116.6 & 113.3 & 29.3 \\
\hline L1 x L5 & -12.9 & -5 & 12.5 & 12.2 & 4.0 & -1.5 & 0.0 & -12.3 & 1.5 & -3.3 & 85.7 & 37.7 & 95.7 & 89.8 & 28.3 \\
\hline L1 x L6 & -14.7 & -8 & 10.9 & 9.5 & -6.9 & -13.3 & 8.6 & 2.8 & 3.3 & -3.3 & 103.9 & 64.9 & 54.5 & 49.4 & 0.4 \\
\hline $\mathrm{L} 1 \times \mathrm{L} 7$ & -17.5 & -9 & 6.8 & 4.3 & 6.1 & 3.3 & 1.5 & -12.3 & 10.4 & 0.0 & 126.6 & 100.6 & 83.7 & 77.5 & 20.8 \\
\hline L1 x L8 & -19.0 & -8 & 9.9 & 6.4 & -2.2 & -11.0 & 4.6 & -14.8 & 6.9 & 14.1 & 62.9 & 15.5 & 73.9 & 69.2 & 10.4 \\
\hline L2 $x$ L3 & -23.9 & -13 & 14.3 & 11.8 & 6.2 & 6.1 & -9.4 & -15.0 & 3.0 & 1.4 & 4.0 & 48.9 & 58.4 & 49.6 & 13.5 \\
\hline $\mathrm{L} 2 \times \mathrm{L} 4$ & -14.4 & -6 & 19.2 & 16.3 & 4.3 & 3.8 & -4.0 & -10.0 & -12.2 & -18.7 & 2.1 & 36.5 & 71.4 & 65.2 & 5.5 \\
\hline $\mathrm{L} 2 \times \mathrm{L} 5$ & -9.4 & -4 & 16.5 & 12.7 & 7.3 & 7.0 & -4.0 & -10.0 & 9.8 & 3.7 & 2.9 & 37.6 & 69.0 & 66.0 & 13.9 \\
\hline L2 x L6 & -19.8 & -11 & 20.1 & 17.0 & 0.8 & -0.5 & 4.2 & -7.5 & 21.7 & 2.8 & 4.5 & 45.8 & 60.2 & 58.0 & 7.0 \\
\hline $\mathrm{L} 2 \times \mathrm{L} 7$ & -20.9 & -10 & 14.2 & 8.2 & -8.0 & -10.3 & -6.6 & -12.5 & 2.2 & -6.6 & 36.7 & 54.0 & 56.6 & 53.3 & 5.9 \\
\hline L2 x L8 & -6.8 & -3 & 15.7 & 11.6 & 0.3 & -1.4 & 11.4 & -2.5 & 2.3 & 0.9 & -3.1 & 11.0 & 50.7 & 48.8 & 0.4 \\
\hline L3 $x$ L4 & -2.5 & 0 & 13.6 & 13.2 & -6.6 & -7.0 & & -2.9 & -20.2 & -23.0 & & 58.6 & 63.9 & 49.0 & 11.2 \\
\hline L3 x L5 & -12.7 & -7 & 19.2 & 17.9 & -1.4 & -1.9 & -5.4 & -5.4 & 11.5 & 10.6 & 4.1 & 41.8 & 65.1 & 59.3 & 21.7 \\
\hline L3 x L6 & -14.6 & -7 & 13.7 & 13.2 & 0.0 & -1.4 & 5.7 & 0.0 & 18.9 & 8.5 & -10.9 & 36.6 & 59.6 & 53.0 & 16.7 \\
\hline L3 x L7 & -19.0 & -8 & 6.7 & 3.2 & 5.5 & 3.3 & -5.4 & -2.8 & 9.6 & 4.8 & 27.6 & 58.6 & 55.3 & 49.8 & 14.8 \\
\hline L3 x L8 & -8.5 & -5 & 18.3 & 16.8 & -6.4 & -8.3 & 7.2 & 2.8 & 8.7 & 20.2 & 5.1 & 22.8 & 67.7 & 60.8 & 22.3 \\
\hline L4 x L5 & -5.0 & -2 & 10.3 & 8.6 & 1.4 & 0.5 & -10.8 & -10.8 & 6.7 & -0.9 & 2.5 & 30.7 & 67.3 & 58.1 & 6.4 \\
\hline L4 x L6 & -15.3 & -6 & 18.4 & 18.3 & -4.4 & -6.3 & 5.7 & 0.0 & 5.2 & -12.1 & 13.0 & 38.3 & 68.0 & 59.7 & 5.9 \\
\hline L4 x L7 & -21.4 & -8 & 11.2 & 7.3 & -6.5 & -8.2 & -13.5 & -11.1 & -0.9 & -6.8 & 34.9 & 31.7 & 42.9 & 33.4 & -8.9 \\
\hline L4 x L8 & -16.0 & -8 & 18.5 & 17.4 & 3.5 & 1.2 & -4.3 & -8.3 & -20.0 & -22.6 & 7.7 & 17.7 & 48.7 & 40.6 & -6.6 \\
\hline L5 x L6 & -13.7 & -6 & 16.4 & 14.7 & -1.8 & -2.8 & -5.7 & -10.8 & -11.8 & -24.9 & -3.9 & 27.8 & 57.8 & 57.0 & 8.5 \\
\hline L5 x L7 & -18.1 & -7 & 5.7 & 3.4 & 1.4 & -1.2 & -16.2 & -16.2 & -3.0 & -11.0 & 24.6 & 34.9 & 48.2 & 47.9 & 3.2 \\
\hline L5 x L8 & -19.5 & -11 & 15.3 & 12.6 & -3.9 & -5.3 & 10.2 & 2.8 & 0.6 & 0.0 & -5.8 & 926.6 & 64.2 & 63.1 & 12.7 \\
\hline L6 x L7 & -13.1 & -6 & 17.3 & 13.2 & 0.2 & -3.3 & 0.0 & -5.4 & 19.5 & -1.8 & 91.1 & 72.2 & 64.0 & 62.9 & 13.2 \\
\hline L6 x L8 & -11.1 & -5 & 19.4 & -13.5 & -4.8 & -4.3 & -1.5 & -13.5 & 16.0 & 6.1 & 40.2 & 17.5 & 44.2 & 25.3 & -1.8 \\
\hline L7 x L8 & -13.8 & -5 & 11.8 & -2.8 & -0.9 & -4.9 & 1.5 & -2.8 & -8.5 & -12.3 & 24.2 & 1.8 & 85.8 & 84.4 & 27.9 \\
\hline
\end{tabular}

\section{Variances Due to GCA and SCA Estimates}

The analysis of combining ability variance components was estimated to determine precisely the importance of additive and dominance components in the inheritance of the traits under study. Mean squares due to GCA and SCA for different traits of maize (Zea mays L.) in $8 \times 8$ diallel crosses are presented in table 5. The mean squares due to GCA for days to maturity, ear diameter, member of kernels per row, 1000 kernel weight and grain yield were significant, indicating the importance of additive genetic variance in controlling these traits. Similar results were reported by other authors in their study on heterosis and combining ability for yield and yield related traits in maize (Dagne et al., 2007; Alam et al., 2008; Aliu et al., 2008; Amiruzaaman et al., 2010; Melkamu, 2013). The mean squares due to SCA were also significant for days to maturity, ear length, member of kernels per row and 1000 kernel weight indicating the importance of nonadditive genetic variance in controlling these traits. GCA: SCA for days to maturity showed that both additive and non-additive gene actions played a role in conditioning days to maturity, number of kernels per row and 1000 kernel weight.

\section{Estimates of GCA of Lines for Yield and Yield Related Traits}

Inbred lines L1, L3, L5 and L7 had good general combining ability for grain yield and these lines may be successfully used in hybrid formation or as component for synthetic cultivar formation. For days to maturity, most of the lines (L2, L3, L4, L5 and L8) showed negative general combining ability effects for the trait indicating that they may be good sources of genes for earliness. Lines 2, 3 and L5 showed good general combining ability for most of the traits studied (table 6).

\section{Estimates of SCA of Crosses for Yield and Yield Related Traits}

Estimates of specific combining effects are depicted in table 7. Most of the crosses exhibited negative values of specific combining ability effects for days to maturity indicating that these specific crosses have good genes for earliness. Several of the crosses showed good specific combining effects for yield and yield component traits. Twelve selected hybrids from the tested hybrid combinations had positive specific combining ability for most of yield related traits and over $10 \%$ standard 
Habtamu Zeleke

heterosis for grain yield (table 8). Some of these identified hybrids may be released for commercial production of the
Sci. Technol. Arts Res. J., July-Sep 2015, 4(3): 32-37

maize crop after testing and verifying their performance at 2-3 locations for about two more years.

Table 5: Mean squares for general combing ability (GCA) and specific combing ability (SCA) for yield and yield related traits in maize

\begin{tabular}{lllcc}
\hline \multirow{2}{*}{ Traits } & \multicolumn{4}{c}{ Mean squares } \\
\cline { 2 - 5 } & GCA (9) & SCA (45) & Error (198) & GCA: SCA \\
\hline DA & $7.18^{* *}$ & $10227.84^{* *}$ & 2.54 & 0.001 \\
EL $(\mathrm{cm})$ & 2.44 & $7.74^{* *}$ & 1.98 & 0.315 \\
ED $(\mathrm{cm})$ & $0.43^{*}$ & 0.18 & 0.13 & 2.389 \\
KRE & 5.29 & 2.55 & 1.98 & 2.075 \\
KR & $105.64^{*}$ & $48.45^{\star *}$ & 22.73 & 0.022 \\
TKWT (g) & $10679.52^{* *}$ & $33596.14^{\star *}$ & 0.013 & 0.318 \\
GY/ha $(\mathrm{kg})$ & $4.45^{\star *}$ & 18.13 & 1.63 & 0.245 \\
\hline
\end{tabular}

Table 6: Estimates of GCA effects of lines for grain yield and yield components in maize at Haramaya, Eastern Ethiopia

\begin{tabular}{|c|c|c|c|c|c|c|c|}
\hline \multirow{2}{*}{ Line } & \multicolumn{7}{|c|}{ Traits } \\
\hline & DM & $\mathrm{EL}(\mathbf{c m})$ & ED (cm) & KR & KRE & TKWT & GY(t/ha) \\
\hline Line 1 & $0.871^{*}$ & $-0.350^{* *}$ & $-0.169^{* *}$ & -0.008 & $-1.946^{\star *}$ & $-21.692^{\star *}$ & 0.165 \\
\hline Line 2 & -0.379 & $-0.186^{\star *}$ & $0.092^{* *}$ & $0.625^{\star *}$ & 0.371 & 5.908 & -0.195 \\
\hline Line 3 & -0.363 & $0.041^{*}$ & 0.011 & -0.008 & $1.038^{* *}$ & 4.708 & 0.459 \\
\hline Line 4 & $-0.996^{*}$ & -0.005 & -0.011 & $-0.308^{* *}$ & $-0.646^{*}$ & -3.542 & -0.408 \\
\hline Line 5 & $-0.779^{*}$ & $0.175^{\star *}$ & $0.082^{* *}$ & $-0.075^{\star *}$ & $1.054^{* *}$ & 13.975 & 0.185 \\
\hline Line 6 & 0.771 & $0.194^{* *}$ & $0.021^{*}$ & $0.192^{* *}$ & $0.738^{*}$ & -4.992 & -0.184 \\
\hline Line 7 & $1.038^{* *}$ & $0.221^{* *}$ & $-0.068^{\star *}$ & $-0.242^{* *}$ & $1.288^{* *}$ & $-12.508^{* *}$ & 0.048 \\
\hline Line 8 & -0.163 & -0.091 & $0.042^{*}$ & $-0.175^{\star *}$ & $-1.896^{* *}$ & 18.142 & -0.070 \\
\hline SE(gi) & 0.784 & 0.0289 & 0.0019 & 0.0289 & 0.3315 & 18.0809 & 0.0238 \\
\hline SE (gi-gj) & 1.792 & 0.0660 & 0.0043 & 0.0662 & 0.7576 & 41.3277 & 0.0544 \\
\hline
\end{tabular}

$\mathrm{ED}=$ ear diameter; $\mathrm{KRE}=$ Kernel rows per ear; $\mathrm{KR}=$ Kernels per ear; $\mathrm{TKWT}$ = thousand kernel weight; $\mathrm{GY}$ = grain yield

Table 7: Estimates of SCA effects for days to maturity, yield components nd agrain yield of maize in $8 \times 8$ diallel crosses

\begin{tabular}{|c|c|c|c|c|c|c|c|c|}
\hline No & Cross & DM & EL (cm) & ED (cm) & KR & KRE & TSW & GY (tons) \\
\hline 1 & L $1 \times$ L 2 & -3.043 & 0.50 & -0.01 & 0.63 & -1.25 & 40.24 & 0.42 \\
\hline 2 & L $1 \times$ L 3 & -1.393 & 1.05 & -0.09 & -0.07 & 1.75 & 35.10 & 0.27 \\
\hline 3 & L $1 \times \operatorname{L~} 4$ & -1.259 & 0.43 & 0.12 & 0.23 & -0.74 & 66.69 & 2.45 \\
\hline 4 & L $1 \times L 5$ & -1.143 & 0.78 & 0.12 & 0.00 & -0.60 & 55.17 & 1.18 \\
\hline 5 & L $1 \times \operatorname{L~} 6$ & -1.526 & 0.23 & -0.23 & 0.73 & -0.12 & 49.47 & -0.04 \\
\hline 6 & L $1 \times$ L 7 & -1.1793 & 0.25 & 0.24 & 0.17 & 3.16 & 46.65 & 1.33 \\
\hline 7 & L $1 \times \operatorname{L} 8$ & -3.593 & 0.04 & -0.11 & -0.23 & -0.65 & 39.00 & 0.63 \\
\hline 8 & L $2 \times \operatorname{L~} 3$ & -6.976 & 0.22 & 0.22 & -1.03 & -0.07 & 34.84 & 0.71 \\
\hline 9 & L $2 \times L 4$ & -3.009 & 0.91 & 0.14 & -0.07 & -3.39 & 10.25 & 0.95 \\
\hline 10 & $\llcorner 2 \times L 5$ & 1.607 & 0.63 & 0.22 & -0.30 & 0.75 & 27.24 & 1.01 \\
\hline 11 & $\mathrm{~L} 2 \times \mathrm{L} 6$ & -4.609 & 0.82 & 0.04 & -0.23 & 0.70 & 36.54 & 0.84 \\
\hline 12 & L $2 x\llcorner 7$ & -4.043 & 0.66 & -0.39 & -0.47 & 0.35 & 65.72 & 0.52 \\
\hline 13 & L $2 \times \operatorname{L~} 8$ & 2.657 & 0.30 & 0.01 & 0.80 & 2.70 & -3.43 & 0.21 \\
\hline 14 & $\mathrm{~L} 3 \times \mathrm{L} 4$ & 3.307 & 0.29 & -0.25 & -0.10 & -5.72 & 40.29 & 0.74 \\
\hline 15 & $\mathrm{~L} 3 \times \mathrm{L} 5$ & -2.076 & 1.23 & -0.08 & 0.00 & 2.41 & 40.44 & 0.97 \\
\hline 16 & $\operatorname{L} 3 \times \operatorname{L} 6$ & -2.126 & 0.09 & 0.08 & 0.40 & 1.06 & -12.43 & 0.95 \\
\hline 17 & L $3 x\llcorner 7$ & -3.393 & -0.31 & 0.25 & 0.17 & 2.01 & 49.09 & 0.56 \\
\hline 18 & L $3 \times$ L 8 & 0.307 & 0.88 & -0.21 & 0.77 & 6.03 & 36.94 & 1.27 \\
\hline 19 & $\mathrm{~L} 4 \times \mathrm{L} 5$ & 1.057 & -0.14 & 0.04 & -0.37 & 2.93 & 16.69 & 0.64 \\
\hline 20 & L $4 \times \operatorname{L} 6$ & -3.326 & 0.76 & -0.11 & 0.70 & -1.25 & 57.49 & 0.97 \\
\hline 21 & L $4 x\llcorner 7$ & -5.093 & 0.36 & -0.25 & -0.53 & 0.36 & 46.00 & -0.43 \\
\hline 22 & L $4 x \operatorname{L} 8$ & -5.226 & 0.89 & 0.23 & -0.27 & -2.12 & 28.19 & -0.13 \\
\hline 23 & L $5 x \operatorname{L} 6$ & -1.876 & 0.58 & -0.05 & -0.87 & -0.12 & 9.97 & 0.58 \\
\hline 24 & L $5 \times \operatorname{L} 7$ & -3.309 & -0.40 & 0.04 & -1.10 & -4.00 & 37.82 & -0.08 \\
\hline 25 & L $5 \times$ L 8 & -5.609 & 0.53 & -0.14 & 1.17 & 1.51 & -9.33 & 0.80 \\
\hline 26 & L $6 \times \operatorname{L~} 7$ & 0.041 & 1.08 & 0.08 & -0.03 & -0.187 & 56.62 & 1.09 \\
\hline 27 & L $6 \times \operatorname{L~} 8$ & -0.159 & 0.81 & -0.08 & -0.10 & 3.16 & 29.14 & 0.03 \\
\hline 28 & L $7 \times$ L 8 & 0.074 & 0.36 & 0.03 & 0.33 & -1.55 & -15.85 & 2.13 \\
\hline
\end{tabular}

L1 = Line 1, L2 = Line 2, L3 = Line 3, L4 =Line 4, L5 = Line 5, L6 = Line 6, L7 = Line 7, L8 = line 8; DA = days to maturity; EL = ear length; $\mathrm{ED}=$ ear diameter; $\mathrm{KRE}=$ Kernel rows per ear; $\mathrm{KR}=$ Kernels per ear; TKWT = thousand kernel weight; $\mathrm{GY}=$ grain yield 
Table 8: Selected $F_{1}$ hybrids based Specific Combining Ability Effects for Yield, Yield component Traits and Standard Heterosis for Yield

\begin{tabular}{|c|c|c|c|c|c|c|c|c|}
\hline \multirow{3}{*}{ No. } & \multirow{3}{*}{ Crosses } & \multicolumn{5}{|c|}{ Specific combining ability effects for yield related traits } & \multirow{2}{*}{\multicolumn{2}{|c|}{ Grain yield }} \\
\hline & & \multirow{2}{*}{$\begin{array}{l}\text { Ear length } \\
\text { (cm) }\end{array}$} & \multirow{2}{*}{$\begin{array}{c}\text { Ear } \\
\text { diameter }(\mathrm{cm})\end{array}$} & \multirow{2}{*}{$\begin{array}{l}\text { Kernel rows } \\
\text { per ear }\end{array}$} & \multirow{2}{*}{$\begin{array}{l}\text { Kernels } \\
\text { per row }\end{array}$} & \multirow{2}{*}{$\begin{array}{c}\text { Thousand kernel } \\
\text { weight }(\mathrm{g})\end{array}$} & & \\
\hline & & & & & & & (t/ha) & STH \\
\hline 1 & $\mathrm{~L} 1 \times \mathrm{L} 4$ & 0.78 & 0.12 & 0.00 & -0.60 & 55.17 & 10.15 & 29.30 \\
\hline 2 & L $1 \times L 5$ & 0.25 & 0.24 & 0.17 & 3.16 & 46.65 & 10.07 & 28.30 \\
\hline 3 & L7 x L8 & 0.36 & 0.03 & 0.33 & -1.55 & -15.85 & 10.04 & 27.90 \\
\hline 4 & L $3 \times$ L 8 & 0.88 & -0.21 & 0.77 & 6.03 & 36.94 & 9.60 & 22.30 \\
\hline 5 & L $3 \times L 5$ & 0.88 & -0.21 & 0.77 & 6.03 & 36.94 & 9.55 & 21.70 \\
\hline 6 & L $1 \times$ L 7 & 0.25 & 0.24 & 0.17 & 3.16 & 46.65 & 9.48 & 20.80 \\
\hline 7 & L $3 \times L 6$ & 0.09 & 0.08 & 0.40 & 1.06 & -12.43 & 9.16 & 16.70 \\
\hline 8 & $\mathrm{~L} 3 \times \operatorname{L} 7$ & -0.31 & 0.25 & 0.17 & 2.01 & 49.09 & 9.01 & 14.08 \\
\hline 9 & L $2 \times L 5$ & 0.63 & 0.22 & -0.30 & 0.75 & 27.24 & 8.94 & 13.90 \\
\hline 10 & L $2 \times L 3$ & 0.22 & 0.22 & -1.03 & -0.07 & 34.84 & 8.91 & 13.50 \\
\hline 11 & L $6 x\llcorner 7$ & 1.08 & 0.08 & -0.03 & -0.187 & 56.62 & 8.89 & 13.20 \\
\hline 12 & L $5 \times L 8$ & 0.53 & -0.14 & 1.17 & 1.51 & -9.33 & 8.85 & 12.70 \\
\hline
\end{tabular}

\section{CONCLUSIONS}

Investigations on combining ability and heterosis have prime importance in maize hybrid development since it provides information for the selection of parents that can be used commercially and also provides information on the nature and magnitude gene actions. In this study, it was found that there is highly significant variation between the genotypes for all the traits considered. Grain yield per hectare and days to maturity were also affected by year of testing showing the need for breeding for specifically adapted hybrids. Hybrid combinations L1 x L4 (29.3\%), L1 x L5 (28.3\%), L3 x L5 (21.7\%) and L1 x L7 (20.8\%) showed high standard heterosis indicating this hybrids could be used for commercial purpose. The mean squares due to GCA for grain yield, days to maturity, ear diameter, member of kernels per row, 1000 kernel weight and grain yield were significant, indicating and inbred lines L1, L3 and L4 are found to be good general combiners for grain yield and these lines can be used as parental components of hybrid formation an; synthetic cultivar and also for further use in the breeding program.

\section{Conflict of Interest}

Conflict of interest none declared.

\section{REFERENCES}

Alam, A.K.M.M., Ahmed, S., Begum, M. and Sultan, M.K. (2008). Heterosis and combining ability for yield and its contributing characters in maize. Bangladesh Journal of Agriculture Research 33(3): 375-379.

Aliu, S., Fetahu, S.H., Salillari, A., (2008). Estimation of heterosis and combining ability in maize (Zea mays L.) for ear weight using the diallel crossing method, Latvian Journal of Agronomy, No.11, LLU.

Amanullah, S., Jehan Mansoor, M. and Khan, M.A. (2011). Heterosis studies in diallel crosses of maize. Sarhad Journal of Agriculture 27(2): 207-211.

Amiruzzaman, M., Islam, M.A., Hassan, L. and Rohman, M.M. (2010). Combining Ability and Heterosis for Yield and Component Characters in Maize. Academic Journal of Plant Sciences 3(2): 79-84.

Asif Ali., Hidayat ur Rahman., Liaqat Shah., Kashif Ali Shah., Shamsur Rehman. (2014). Heterosis for grain yield and its attributing components in maize variety Azam using linextester analysis method. Academia Journal of Agricultural Research 2(11): 225-230.

CSA (Central Statistical Agency), (2013). Agricultural sample survey. Report on farm management practices. Private peasant holdings, Meher season. Statistical Bulletin. Addis Ababa, Ethiopia. pp. 6-9.

CSA (Central Statistical Agency), (2014). Agricultural sample survey. report on area and production of major crops Private peasant holdings, Meher season). Statistical Bulletin. Addis Ababa, Ethiopia.

Dagne Wegary Gissa., Zelleke, H., Labuschagne, M.T. Hussien, T. and Singh, H. (2007). Heterosis and combining ability for grain yield and its components in selected maize inbred lines, South African Journal of Plant and Soil 24(3): 133-137,

Griffing, B. (1956). Concept of general and specific combining ability in relation to diallel crossing system. Australian Journal of Biological Sciences 9: 463-493.

Habtamu, Z. and Hadji, T. (2010). Combining ability analysis for yield and yield related traits in quality protein maize (Zea mays L.) inbred lines. International Journal of Biological Sciences 2(7): 87-97.

Hayes, H.K., Immer, F.R., Smith, D.C. (1955). Methods of Plant Breeding. Mc. Grow Hill Book. Co., Inc., New York. P. 19.

Melkamu Elmyhum (2013). Estimation of combining ability and heterosis of quality protein maize inbred lines, African Journal of Agricultural Research 8(48):6309-6317.

Rahman, H., Arifuddin, Z., Shah, S., Shah, A., Iqbal, M. and Khalil, I.H. (2010). Evaluations of maize $S_{2}$ lines in test cross combinations I: flowering and morphological traits. Pakistan Journal of Botony 42(3): 1619-1627.

Rodrigo Oliboni., Marcos Ventura Faria., Mikael Neumann., Guilherme Mendes Battistelli., Rafael Gallo Tegoni and Juliano Tadeu., Vilela de Resende (2012). Genetic divergence among maize hybrids and correlations with heterosis and combining ability. Maringá 34(1): 37-44.

Shushay Welderufael Abrha (2014). Top Cross Analysis of Maize (Zea mays L) Inbred Lines for Some Agronomic Traits in Central Rift Valley of Ethiopia. Journal of Biology, Agriculture and Healthcare 4(25): 8-13. 